\title{
Exposure as Collected Route of Administration
}

National Cancer Institute

\section{Source}

National Cancer Institute. Exposure as Collected Route of Administration. NCI Thesaurus.

Code C117486.

The means of entry through which the exposure is taken into the body. 